\title{
La frontera entre la palabra y la imagen en Las ciudades invisibles de Italo Calvino y Pedro Cano: el proceso de construcción del álbum ilustrado 1
}

\section{The border-line in the write and the image in The invisible cities by Italo Calvino and Pedro Cano: the development of the album}

\author{
Gloria LAPEÑA GALLEGO \\ Universidad de Murcia \\ gloria.lapena@um.es
}

Recibido: 01-09-2013

Aceptado: 13-03-2014

\section{Resumen}

El presente estudio toma como ejemplo Las ciudades invisibles en dos formas narrativas: el relato (Italo Calvino) y la pintura (Pedro Cano), con el fin de establecer diferencias entre la palabra y la imagen. Si bien el pintor murciano se inspira en el libro de Calvino para realizar sus acuarelas "encargo" de la viuda del escritor, de manera similar proceso que se lleva a cabo en la elaboración del libro ilustrado, su unión física original se va eliminando de manera natural hacia la exposición en la galería. Esta evolución es muy similar a la del álbum ilustrado, un producto que ha derivado del libro ilustrado con tendencia a perder la redundancia expresiva que caracteriza a este último. El álbum ilustrado adquiere en su proceso creativo una dualidad, no duplicidad, en perfecto equilibrio entre ambas formas de expresión, escritura e imagen.

Palabras clave: palabra-imagen, álbum ilustrado, libro ilustrado, pintura, relato.

\footnotetext{
1 Este trabajo de investigación forma parte de la Tesis Doctoral financiada con una ayuda predoctoral (19099/FPI/13) con cargo al Programa de Formación del Personal Investigador de la Fundación Séneca, Agencia de Ciencia y Tecnología de la Región de Murcia en el marco del III PCTRM 201114.
} 


\begin{abstract}
This study takes the example of Le città invisibili narratives in two forms: the story (Italo Calvino) and painting (Pedro Cano). The purpose is to differentiate between the write and the visual image. The widow the writer instructs Cano illustrate the fifty-five cities, similar to the picture book. However it is not possible to merge image and writing. Finally, Cano's watercolors are similarly exposed. This is similar to the evolution of the album from illustrated the picture book. The album in the creative process acquires a duality, not duplication, in perfect balance between the two forms of expression.
\end{abstract}

Keywords: write-visual image, the album, picture book, painting, narrative.

\title{
1. Introducción
}

La utilización de códigos del lenguaje escrito origina obras literarias de significación autónoma e independiente del contexto en el que se manifiestan. Se toma así la palabra como referente y como una de las formas más perfectas de comunicación social, siendo aprovechada como medio democratizador e igualitario. Sin embargo, el poder actual de la imagen ha provocado que nos sintamos seducidos por el mundo visual al mismo tiempo que, paradójicamente, no podemos prescindir de la palabra. De este modo, aunque la creación literaria siempre se haya estudiado desde el punto de vista lingüístico y estético no-verbal, las nuevas formas narrativas híbridas obligan a hablar de otros modos de escritura y de opciones artístico-plásticas con una ubicación poco clara hacia la Literatura o hacia las Bellas Artes.

La línea que delimita escritura e imagen ha sido dibujada sin problemas hasta la invasión de lo visual. Tomás (1998) ${ }^{2}$ parte de los trabajos de Claude Lévi-Strauss (La pensée sauvage) y de Marshall McLuhan (La galaxia de Gutenberg), editados en 1962. Ambas obras enfrentan la escritura alfabética, es decir, lo racional, a las imágenes sensibles, lo mágico. Los atributos racional y mágico que utiliza Tomás son sinónimos a los términos científico y salvaje de Lévi-Strauss en su obra La pensée sauvage ${ }^{3}$. La dialéctica entre escritura e imagen sirve como base para establecer las relaciones entre racionalidad y magia. En ambos casos se establece un predominio de la escritura material sobre la imagen espiritual. Igualmente los sitúan en diferentes planos: uno lineal o matemático jerarquizado para la palabra y otro multidimensional o estadístico, en el que la mirada y la percepción de la imagen establecen las relaciones entre los múltiples significantes.

2 Tomás, F., Escrito, pintado, Visor, Madrid, 1998.

3 Levi-Strauss, C., El pensamiento salvaje, Fondo de Cultura Económica de España, Madrid, 1964. 
El ámbito literario analizado por Tomás puede trasladarse al artístico. La realidad queda en un plano tangible, mientras que la obra plástica en otro protagonizado por la selección y la sustitución, ya que no puede, en términos derridianos, reproducir nada ${ }^{4}$. Se trata de la idea clásica del no-mimetismo en el Arte y que obliga a escribir sobre ciertos artistas y sus obras retomando lo que ya está escrito acerca de ellas o cualquier letra, firma, palabra que la legitime. Para Derrida, el privilegio tradicional de lo visible está fundamentado y desbordado por el privilegio del tacto, la huella o la escritura5.

La mayoría de las publicaciones orientadas a relacionar la palabra con la imagen dentro del ámbito de la creatividad plástica se refieren a los medios audiovisuales, cine, televisión e incluso internet, encuadrados dentro de la denominada Cultura Visual. Esta disciplina surge a finales del siglo XX desde la historia del arte como una necesidad para someter a nuevo objeto de estudio la visualidad6. Sin embargo, ni la entidad Cultura Visual está aún suficientemente definida, ni se encuentra restringida a la tecnología digital. Según Bal, la visualidad no solo es una propiedad característica y definitoria de los objetos, sino también los actos de visión hacia esos objetos, hasta el punto de que ciertos textos puramente literarios solo tienen sentido visualmente por su mezcla sensorial y por los nudos afectivos y cognitivos en el acto perceptual.

El presente estudio pretende ahondar en el Álbum Ilustrado como forma de narración fundamentalmente visual sin olvidar su origen y evolución a partir del libro ilustrado en el que la escritura es la responsable del hilo narrativo. No se trata de analizar su estructura o características, cuestión a la que se dedican la mayoría de los trabajos publicados, sino de establecer las relaciones entre texto e imagen en el proceso creativo y la dualidad existente en la escritura y la imagen que originan un fluido trasiego de un lado al otro sin solución de continuidad. Un ir y venir de dos modos de expresión aparentemente distintos sin llamar la atención cuando se unen en el mismo espacio físico y temporal. Así podemos encontrar libros de artistas plásticos que componen poemas para acompañar sus ilustraciones ${ }^{7}$, ilustradores que narran $\sin$ texto $^{8}$, e incluso escritores que se introducen como pintores a partir de la edición de un libro ilustrado y posteriormente crean obras con cuerpo propio como para poder contemplarse de manera independiente 9 . Nos encontramos ante un producto artístico que gradualmente queda desglosado y que se reproduce en forma

\footnotetext{
${ }^{4}$ Galard, J., «La obra exapropiada. Derrida y las artes visuales». En Escritura e imagen, 2, 2006, pp. 57-70.

5 Derrida, J., Le toucher, Jean-Luc Nancy, Galilée, París, 2002.

${ }^{6}$ Bal, M., «El Esencialismo visual y el objeto de los Estudios Visuales». Estudios visuales, 2, 2004, pp. 11-49.

7 Liao, J., Hermosa soledad, Barbara Fiore Editora, Madrid, 2008.

8 Tan, S., El rey pájaro y otros esbozos, Barbara Fiore Editora, Madrid, 2011.

9 Michaux, .H., Entre centre et absence, H. Matarasso, Paris, 1936.
} 
de libro ligado a la narración, al tiempo que se expone en nuevos espacios, como por ejemplo la Exposición Anual Premio Internacional de Ilustración Feria de Bolonia, que tienen que ver más con la galería que con la librería. En definitiva, un destino lógico y natural que surge de la inercia hacia la expresión de ideas por distintas vías de escape sin posibilidad de una clasificación estanca en escritura o imagen. El álbum ilustrado como cultura visual no se encierra en la obra plástica como objeto visible, sino como acto narrativo. Al mismo tiempo, la semiótica del cuento o narración literaria van más allá del análisis lingüístico.

Para llevar a cabo nuestro estudio tomamos dos obras que, con el título Las ciudades invisibles, se presentan bajo dos formas distintas: una narración escrita en forma de libro (Italo Calvino10) y una obra plástica formada por un conjunto de acuarelas con los mismos títulos a los de los nombres de las ciudades de la narración (Pedro Cano ${ }^{11}$ ). Ambos no persisten unidos en el formato libro que caracteriza cualquier álbum, sino que cada uno constituye una obra autónoma. La finalidad es acercarnos al concepto de álbum ilustrado, confuso con el del libro ilustrado a partir del que evoluciona. La materia de la que está hecha la imagen no tiene relación alguna con lo que allí se interpreta, por lo que cualquier asignación de normativa para relacionar los códigos visuales con los lingüísticos estará supeditada al acto de visión hacia la imagen, propio del método analítico de la cultura visual. Por tanto, mientras que en el libro ilustrado son la misma cosa expresada con distinto lenguaje, el álbum tiene una doble aportación, la real (escritura) y la mágica (imagen). Esta dualidad obliga a establecer normas formales o académicas para una obra que se circunscribe artificialmente en el clásico libro, pidiendo irremediablemente ser liberado hacia formas artísticas nuevas independizadas del libro ilustrado, valorado fundamentalmente desde la semiótica lingüística.

\section{Concepto álbum ilustrado}

Desde un punto de vista artístico, literatura y pintura tienen la suficiente entidad como para dar fruto a una obra de calidad y gran belleza en sí misma. Sin embargo, los medios visuales y verbales se presentan juntos en numerosas ocasiones a lo largo de la Historia. Grabados, dibujos alegóricos e iconos han tratado de explicar y aclarar textos que por su semántica o por su composición se presentaban ante la sociedad como inalcanzables. En dirección inversa, a través de un lenguaje propio de las artes, los sentimientos del artista son puestos en boca de críticos para dar una

\footnotetext{
10 Italo Calvino, Las ciudades invisibles, traducción Aurora Bernárdez, Ediciones Siruela, Madrid, $2011\left(20^{\mathrm{a}}\right.$ ed).

11 Pedro Cano, Las ciudades invisibles, Catálogo Exposición, Sevilla 1 de diciembre 2006 al 14 de enero 2007, Comunidad Autónoma de la Región de Murcia, Murcia, 2006.
} 
interpretación a todo lo que subyace y desborda la obra sujeta a una temporalidad y limitación física y que es necesario conservar y transmitir. Ambos extremos, en los que predomina uno de los dos tipos de lenguajes artísticos, tienen su máxima interrelación en el libro ilustrado, espacio donde la duplicidad de información resulta ser una redundancia intencionada y recreativa de la narración.

El álbum ilustrado deriva de una manera progresiva del libro ilustrado. En su origen la imagen queda supeditada a las directrices del lenguaje verbal, que se mantenía en un nivel superior. Posteriormente su evolución y contaminación con herramientas, técnicas y corrientes plásticas más modernas, desemboca en un tipo de arte visual en el que la utilización del libro es solo una excusa para que los creativos disparen su imaginación en las direcciones más diversas hacia la búsqueda de una genialidad que no admite limitaciones.

Como sucede con cualquier producto nuevo, su definición plantea un problema complejo, en este caso una especie de disputa entre literatos y artistas plásticos, con un predomino claro de los primeros. Las principales investigaciones se analizan desde una óptica de literatura infantil y juvenil, enfocadas al estudio de la cohesión narrativa ${ }^{12} \mathrm{o}$ al enriquecimiento creativo del lector mediante la función de la ilustración añadida por un segundo emisor con un nuevo lenguaje no previsto por el autor literario ${ }^{13}$. Surgen así aproximaciones cada vez más perfiladas y en 2007, Emma Bosch lo califica de "arte visual de imágenes secuenciales fijas e impresas afianzado en la estructura de libro, cuya unidad es la página, la ilustración es primordial y el texto puede ser subyacente14", categorización que por una parte lleva el álbum al campo de la cultura visual y por otra lo aproxima a un formato editorial con escasas posibilidades o con restricciones poco salvables por la creatividad. Quizás el problema resida en su carácter multidisciplinar y como tal deba ser reexaminado por separado antes de su clasificación. Al igual que las nuevas culturas visuales la simultaneidad entre textos e imágenes actúa por discrepancias enigmáticas entre ambos registros, sin llegar a ser fotografías que ilustran el texto ni palabras que explican las imágenes ${ }^{15}$.

\footnotetext{
12 Turrión Penelas, C., «La ambigüedad de significado en el álbum y su lector implícito. El ejemplo de El Túnel de Browne», Bellaterra Journal of Teaching \& Learning Language \& Literature, 5 (1), 2012, pp. 60-78.

13 Díaz Armas, J., «La imagen en pugna con la palabra», Saber educar, 13, 2008, pp. 43-57.

14 Bosch, E., «Hacia una definición de álbum». AILIJ, Anuario de Investigación de Literatura Infantil y Juvenil. Universidad de Vigo, 5, 2007, pp. 25-45.

$15 \mathrm{Bal} 2004$, op.cit. (nota 5).
} 


\section{Las ciudades invisibles: la palabra}

En la nota preliminar de la $20^{\text {a }}$ edición de Las ciudades invisibles ${ }^{16}$ se recogen algunas de las manifestaciones públicas que el propio Calvino realizó sobre su libro desde su publicación en noviembre de 1972 hasta comienzos de 1973 y su conferencia para los estudiantes de la Graduate Writing Division de la Columbia University de Nueva York (marzo, 1983). Calvino sitúa el origen de su libro en ciudades inventadas que sirven de punto de partida de una reflexión y escritos como poemas. A lo largo de una serie de años toma apuntes que coloca en diferentes carpetas de viaje, convirtiéndose en un diario de reflexiones y estado de humor. La clasificación de las ciudades es una de las complicaciones que encontró Calvino, resultando finalmente en 11 series de 5 textos cada una, en los que se Marco Polo relata a Kublai Kan, emperador de los tártaros, lo que ocurre en escenarios imposibles, todo acompañado de reflexiones que corren paralelas. Se impone así una duplicidad en cuanto a ciudad atemporal arcaica-moderna, lugar de memorias y deseos. La ciudad de la memoria es la imagen de la ausencia, presente en las evocaciones de Marco Polo en el punto central del libro, y la de los deseos es la ciudad utópica que nunca se deja de buscar. Las ciudades son el principal elemento articulador en el texto literario y el acto de visión hacia ellas el punto de partida teorético.

Las imágenes de Calvino, pintadas por medio de la palabra, no quedan muy alejadas de la imagen cartográfica de Benjamin en Crónica de Berlín (1932)17, cuando escribe por primera vez de sí mismo de una manera subjetiva y articulando su vida en un mapa militar de la ciudad de Berlín. El color gris sería el fondo para colocar colores de los lugares importantes, un "espacio de vida". Esta forma de la Berlín vivida tiene relación con su admiración por Marcel Proust y la concepción de lo auténtico en lo ínfimo ${ }^{18}$ que hace que cada uno escriba su propio libro interior, predominando la profundidad y lo sustancial sobre lo superficial y las apariencias 19 . Sobre esta reflexión se insiste en diferentes textos como Sobre algunos temas en Baudelaire (1939) ${ }^{20}$ y Materia y memoria (1959) ${ }^{21}$. Se erige una nueva manera de entender la sensibilidad más allá del control consciente y subjetivo de la sociedad del siglo XX. Hablamos de objetos concretos, palabras recordadas, aromas y ruidos para hacer frente a la objetividad y esforzarse en escuchar las cosas insignificantes que no deben darse por perdidas en la historia porque el tiempo dé pistas falsas

\footnotetext{
17 Benjamin, W., Escritos Autobiográficos, Alianza, Madrid, 1996.

18 Pinilla Burgos, R., «Memoria y sensibilidad en Walter Benjamin». En Bajo Palabra. Revista de Filosofia, 5, 2010, pp. 69-78.

19 Sánchez Ruiz, J. \& López Aparicio, I., «La memoria: una estructura para la creación». Arte, Individuo y Sociedad, 20, 2008, pp. 21-42.

20 Benjamin, W., Sobre algunos temas en Baudelaire, Leviatan, Buenos Aires, 1999.

${ }^{21}$ Bergson, H., Materia y memoria, Aguilar, México, 1959.
} 
sobre la verdad. El mapa representado por Benjamin ocurre a posteriori de su experiencia durante la infancia y lo sitúa en una atemporalidad paradójicamente futurista del desastre que tendría lugar en la ciudad tras la Gran Guerra. Las ciudades invisibles de Calvino son una "cartografía privada22" que se dibujan y desdibujan en cada capítulo del libro. No imposibilitan otro camino que no sea el que está inscrito en el mapa ni deciden el tiempo en el que existieron unas y otras ciudades. Los límites que se pretenden mediante acotaciones de lugares parten de una experiencia individual apoyada en objetos, movimientos y gestos creados, dibujados, para reconstruir la historia de lo cotidiano.

El grado máximo de abstracción y eliminación total de la palabra en una narración sobre la ciudad, lo encontramos en Emigrantes de Shaun Tan' ${ }^{23}$, una historia de una emigración contada exclusivamente con imágenes y que surge a partir de Esbozos de una tierra sin nombre ${ }^{24}$, libro ilustrado con notas y bocetos de otros artistas. La ciudad miserable de la que parte para prosperar el protagonista se transforma en una ciudad enloquecida llena de metáforas, símbolos y representaciones. El estilo meticuloso de dibujo a base de infinitos trazos que pretende atrapar todas las sensaciones y emociones de la familia en el momento de la despedida es comparable a la descripción de Calvino de Zaira:

Una descripción de Zaira tal como es hoy debería contener todo el pasado de Zaira. Pero la ciudad no cuenta su pasado, lo contiene como las líneas de una mano, escrito en las esquinas de las calles, en las rejas de las ventanas, en los pasamanos de las escaleras, en las antenas de los pararrayos, en las astas de las banderas, cada segmento surcado a su vez por arañazos, muescas, incisiones, comas. ${ }^{25}$

En el extremo opuesto, la secuencia de una flor sencilla sujeta al paso del tiempo en Emigrantes, se hace notar en Procopia: "así, un año tras otro, he visto desaparecer el foso, el árbol, el zarzal ocultos por setos de sonrisas tranquilas, entre las mejillas redondas que se mueven masticando hojas". 26

La particularidad más manifiesta de la obra de Calvino es su carácter eminentemente visual en el que la escritura materializa lo inmaterial, la imaginación subjetiva del escritor. Los iconos que se muestran por medio de la expresión verbal son imágenes de imágenes, "hipericonos $27 "$, y promueven en el lector a su vez otras

22 Campillo García, D., «Cartografías privadas a propósito de Las ciudades invisibles explicadas por Italo Calvino». Actas Icono 14. II Congreso Internacional de Ciudades Creativas, Revista de Comunicación y Nuevas Tecnologías, 10, 2011, pp. 1-12.

23 Tan, S., Emigrantes, Barbara Fiore Editora, Madrid, 2011.

24 Tan, S., Esbozos de una tierra sin nombre, Barbara Fiore Editora, Madrid, 2011.

25 Calvino 2011, op.cit. (nota 9), pp. 25-26.

26 Ibid, pp. 154-155.

27 Mitchell, W.J.T., Iconology: Image, text, Ideology, University of Chicago Press, Chicago, 1986. 
imágenes mentales en el acto visual. La escritura (lo real) va más allá de la literatura para llegar a la imagen (lo mágico) de acuerdo con la dialéctica amistosa entre pictograma y escritura. La teoría del lenguaje de Blake se orienta hacia la invisibilidad, puesto que considera que la escritura, medio de la ausencia y del artificio, desplaza la imagen, medio de la presencia y la naturaleza 28 . Por tanto la verdad profunda, según Blake, no tiene imagen. Sin embargo para Derrida lo visible no se ciñe exclusivamente a lo que el ojo ve sino que queda supeditado al tacto o huella, como el ciego que camina extendiendo las manos para tocar las cosas. Ambas teorías no se contradicen si atendemos al concepto de "hipericonos", que van más allá de la mera descripción literal para evocar otras imágenes, las que se hacen visibles por medio de sensaciones.

\section{Las ciudades invisibles: la imagen}

La obra del pintor murciano Pedro Cano se caracteriza por su huida de la copia de la realidad para alcanzar la ensoñación, la huella que deja la existencia en las cosas. La ausencia y la soledad desbordan lo pictórico para dar paso a la memoria, tanto en sus óleos sobre grandes lienzos como los lápices o acuarelas sobre papel29, un soporte protagonista de lo que ocurre a su alrededor. En sus propias palabras:

A mí lo que me gusta es que la gente vuelva a ver el cuadro, o sea que no pueda leerlo en un momento, sino que se identifique como una cosa personal, poder ahondar a través de mis propios sentimientos en los suyos. ${ }^{30}$

$\mathrm{Su}$ forma particular de trabajo es la agenda libro o cuaderno de viaje en el que apunta escritura, bocetos e ilustraciones para posteriormente transformarlas en obras, acuarelas que pueden ser expuestas, y de hecho así lo hace con frecuencia, en una galería o museo. Son por tanto la idea del quehacer diario, el presente legitimado por la fecha impresa, billetes o sellos, a la vez que planes para el futuro. El viaje a lugares dispares como Libia, Yemen o Egipto y la literatura como pretexto son fuentes de inspiración.

Lo que hace única a Las ciudades invisibles de Cano es la dedicación de toda una obra a un libro completo y la inspiración en la ficción sin presencia de lo real. Calvino y Cano, que sentían admiración mutua, se conocieron personalmente en Roma en 1984, durante la inauguración de una exposición en la Gallería Giulia de

\footnotetext{
28 Mitchell, W.J.T., Teoría de la Imagen, Akal, Madrid, 2009.

29 González Sánchez, M., El pintor Pedro Cano, Servicio de Publicaciones Universidad de Murcia, Murcia, 2009.

30 Iraburu, B., Se pinta como se va a una fábrica, La Verdad, Murcia, 22 diciembre 1998, p. 56.
} 
Roma. En 1988, durante otra exposición en Roma, ya fallecido Calvino, Cano recibe se su viuda un ejemplar de la primera edición de Las ciudades invisibles con la sugerencia de que lo utilizase de inspiración. El ofrecimiento queda convertido en un reto al que se enfrenta Cano ante una narración fantástica para plasmar lugares imposibles y asincrónicos que no aparecen en ningún atlas "ni se sabe si son del pasado, presente o futuro 31 ". Se trata de materializar la palabra en imagen, pero a diferencia del ilustrador de libros, sin normas de formato por parte de editoriales ni supeditado a cualquier definición sobre el tipo de inspiración al que deba someterse.

Cano realiza los bocetos en el propio libro, imbricados e incluso ocultando palabras e invadiendo cualquier espacio antes de ser víctima del horror vacui. Al cabo de los años y después de viajes, inspiraciones y bocetos, se embarca en la tarea de convertirlos en 55 acuarelas sobre papel de $30 \times 50 \mathrm{~cm}$, una por cada Ciudad de Calvino. Mezclas de tonalidades verdes, amarillas, anaranjadas, ocres y rojas pasan del libro al museo, como una contradicción con la democratización del arte que invade el espacio público con nuevas culturas artísticas, y no por ello un retroceso hacia un pasado en el que la obra queda restringida a un grupo selecto, sino más bien por una necesidad o lógica, comparable a la exposición internacional de ilustración en Bolonia tras la Feria en el mismo lugar organizada por editoriales. Un ejemplo de esta migración es la que se muestra con la ciudad Fedora, uno de los capítulos de Las ciudades invisibles que comienza:

En el centro de Fedora, metrópoli de piedra gris, hay un palacio de metal con una esfera de vidrio en cada aposento. Mirando el interior de cada esfera se ve una ciudad azul que es el modelo de otra Fedora. Son las formas que la ciudad hubiera podido adoptar si, por una u otra razón, no hubiese llegado a ser como la vemos. Hubo en todas las épocas alguien que, mirando a Fedora tal como era, imaginó el modo de convertirse en la ciudad ideal, pero mientras construía su modelo en miniatura Fedora ya no era la misma de antes y lo que hasta ayer había sido su posible futuro ahora sólo era un juguete en una esfera de vidrio. ${ }^{32}$

31 Declaración de Pedro Cano en entrevista para la agencia EFE, el 26 de febrero de 2006 según p. 153 de González Sánchez, 2009.

32 Calvino 2011, op.cit. (nota 9), pp. 45-46. 


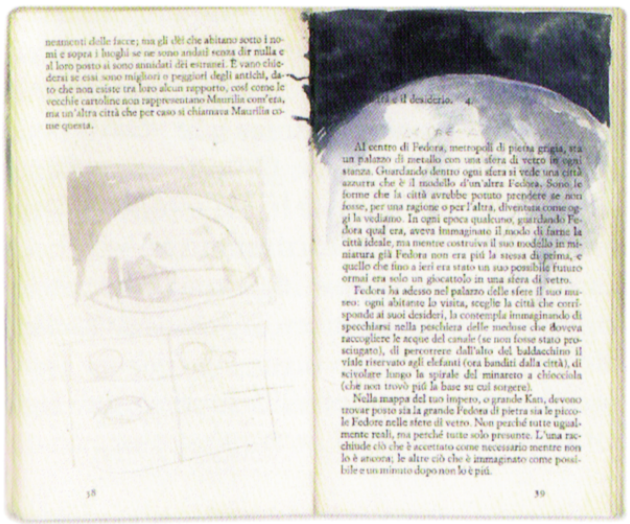

Figura 1. Boceto de Fedora realizado por Pedro Cano sobre las páginas consecutivas en las que Calvino finaliza la descripción de Maurilia y comienza con la de Fedora ${ }^{33}$.

La ilustración e interpretación que realiza Cano sobre Fedora bien podría dar lugar a la pertinente pregunta sobre la prioridad del huevo o la gallina, especialmente si se desconoce la cronología en la génesis de ambas obras, literaria y plástica. Se trata de un ejemplo más próximo a un texto ilustrado o todo lo contrario, a una écfrasis o representación verbal de la representación visual. Su redundancia encaja perfectamente en una página de un libro ilustrado en la que se describe una ciudad imaginaria atemporal y fantástica que precisa de una aclaración mutua para ser precisada.

El ejemplo descrito no constituye la tónica general de la mayor parte de las acuarelas, sino que en ellas se introducen particularidades que crean esa frontera entre imagen y palabra necesaria para la dualidad de información que hemos planteado como hipótesis de este estudio e inexistente en el libro ilustrado. Así, a la derecha de cada imagen de las acuarelas de Cano aparecen dos letras que son la inicial de cada nombre que Calvino le da a las ciudades, siempre con una nominación femenina. Ambas letras, extraídas de alfabetos (la mayor parte de ellos antiguos) están, tal y como revela el autor, para testimoniar cómo dos signos absolutamente distintos tienen el mismo sonido. En el caso concreto de nombres que comiencen por la letra de sonido /e/ para las ciudades-mujeres, Eufemia ${ }^{34}$, Eutropia 35 , Ersilia ${ }^{36}$, Esmeraldina ${ }^{37}$ Eudoxia ${ }^{38}$ y Eusapia ${ }^{39}$ representa dieciséis grafismos dis-

\footnotetext{
33 Imagen tomada de González Sánchez 2009, op. cit. (nota 28), p. 151.

34 Calvino 2011, op.cit. (nota 9), pp. 50-51.

35 Ibídem, pp. 78-79.

36 Ibidem, p. 90.

37 Ibídem, pp. 101-102.

38 Ibídem, pp. 109-110.

39 Ibídem, pp. 121-122.
} 
tintos, anulando la precisión del lenguaje que parece contar la verdad apuntada por Tomás y Levi-Strauss, frente a lo mágico de la imagen, o más bien el hipericono, la imagen de la imagen. Es posible que este hecho haya sucedido de una manera totalmente involuntaria, si bien el propio Cano manifiesta:

Para mí es más válida una palabra para crear una imagen que una imagen para crear una palabra porque la imagen es muy estable, mientras que la palabra la conserva siempre, o sea, tiene el jugo de las cosas y te las devuelve frescas. La palabra evoca enormemente. Por ello pienso que la palabra tiene entre todas las posibilidades expresivas el máximo de libertad, (y) no condiciona. 40

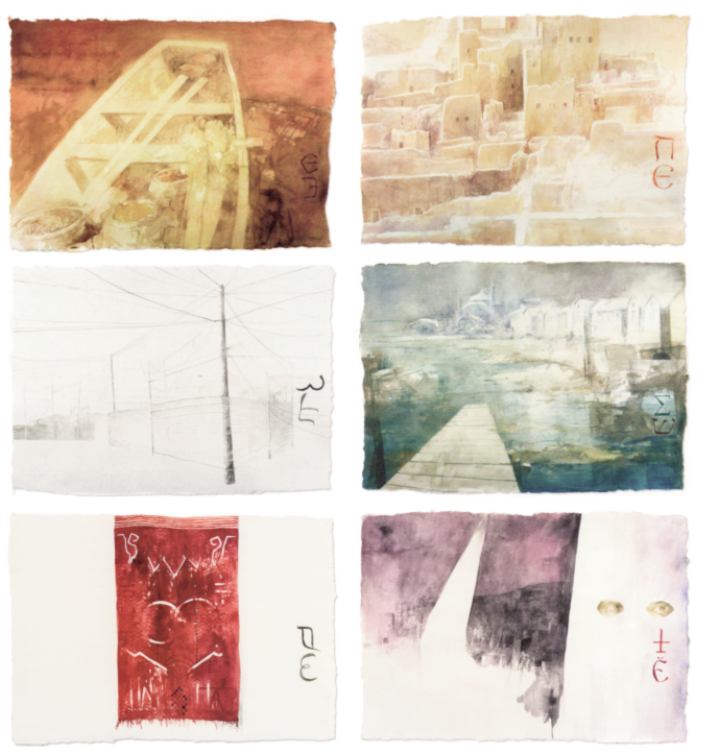

Figura 2. Diferentes letras con el sonido /e/ en las acuarelas de las ciudades Eufemia, Eutropia, Ersilia, Esmeraldina Eudoxia y Eusapia41.

Pero donde más se manifiesta la doble aportación en esta obra, la dualidad, es en la metáfora. Aquellas acuarelas en las que Cano se aleja de los elementos propiamente urbanos como puentes, edificios, tejados o ventanas, y se introduce en un lenguaje simbólico de fusión de fantasía - la desencadenada por las palabras de Calvino-y realidad -las imágenes observadas por Cano en sus viajes por distintos países-. Así, Despinia a la que se puede llegar "en barco o en camello. La ciudad es diferente para el que viene por tierra y para el que viene por mar42", según des-

\footnotetext{
40 Pedro Cano, Una specie di diario. Giornale di viaggio, Galeria Giulata, Roma, 1079, p. 1.

41 Imágenes tomadas respectivamente de Cano 2006, op.cit. (nota 10), pp. 20, 21, 32, 33, 16 y 16.

42 Calvino 2011, op.cit. (nota 9), pp. 32-33.
} 
cribe Calvino. Para Cano es un primer plano con dos vasos transparentes cada uno de ellos con arena y agua y la ciudad insinuándose apenas en el infinito. Maneras de ver las cosas, la confusión de las imágenes similares al sombrero/elefante engullido por una serpiente de El Principito ya están reforzadas previamente por el texto literario de Calvino, considerado clásicamente más preciso.

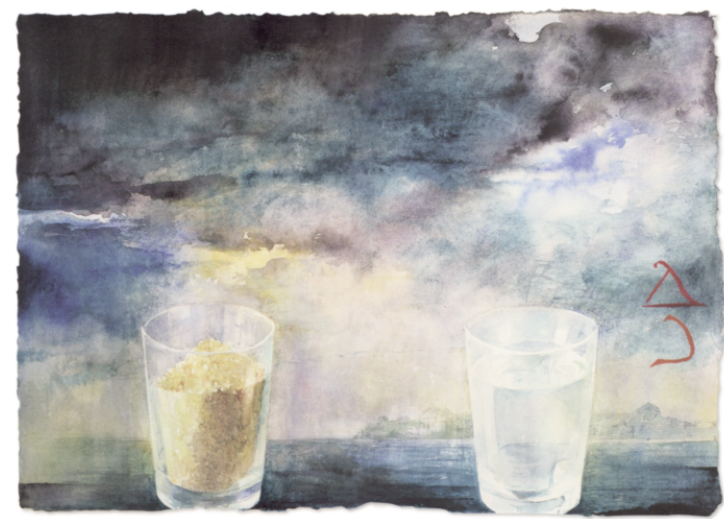

Figura 3: Despinia43

Todo el registro de imágenes poéticas en las que se alternan abstracciones, signos y concreciones, lo acompaña Cano de breves párrafos que los utiliza a modo de título, en un intento de enlazar el texto de Calvino con sus acuarelas. Para Zoe elige "Cada hombre lleva en su mente una ciudad hecha solo de diferencias... ${ }^{4}$ " y la representa por medio de dos figuras geométricas sencillas, triángulo y rombo, sobre tonos ocres. La mayor abstracción geométrica es para Zemrude "es el humor de quien la mira el que da su forma a la ciudad de Zemrude45", un humor sucintamente expresado por colores herrumbrosos y verdes. La elección de estos dos ejemplos es un tanto intencionada en cuanto a la invasión de los textos pictoriales ${ }^{46}$, etiquetas en las paredes de los museos que ocupan mayor tiempo al espectador que las propias imágenes y que pueden suponer desde una distracción o aclaración hasta una negación ${ }^{47}$.

\footnotetext{
43 Imagen tomada respectivamente de Cano 2006, op.cit. (nota 10), pp. 12 y 13.

44 Calvino 2011, op.cit. (nota 9), pp. 47-48.

45 Calvino 2011, op.cit. (nota 9), p. 80.

46 Título que le da W.J.T. Mitchell 2009, op. cit. (nota 27) a su ensayo, pp. 187-284 para hablar de la pintura abstracta, de los objetos y del ensayo fotográfico.

47 Foucault, M., Esto no es una pipa. Ensayo sobre Magritte, Anagrama, Barcelona, 1993 (3 ed).
} 

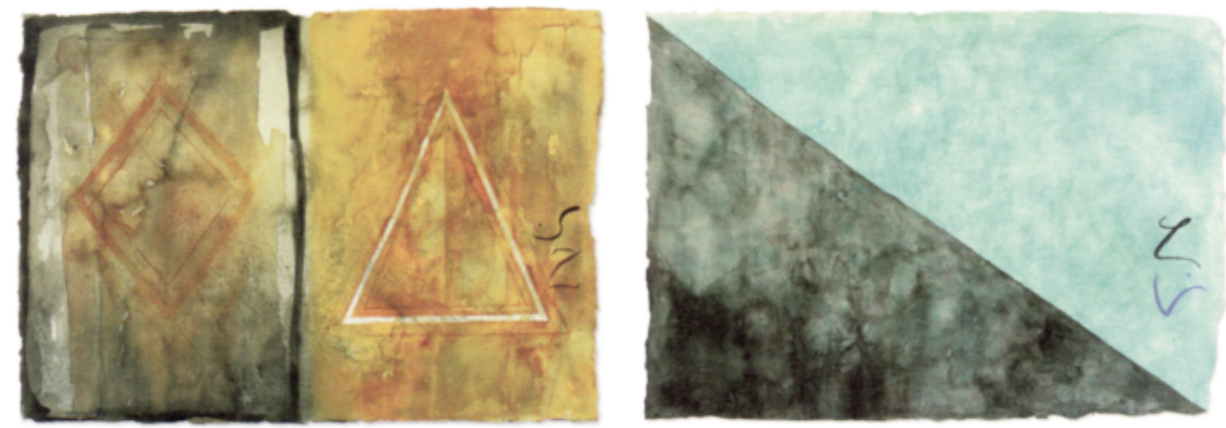

Figura 4: Zoe y Zemrude 48

\section{Las ciudades invisibles: ¿un álbum ilustrado?}

Si retomamos la definición más reciente y consensuada del álbum ilustrado sobre su calidad de "obra de arte" con un formato editorial definido por una estructura, número de páginas, dominio de la imagen sobre el texto y guardas en diálogo con el contenido, lo primero que llama la atención es la elevación de la labor, prácticamente oculta, del ilustrador de libros hasta el estatus de artista, en cuanto a que dice algo nuevo sobre a la aportación literaria y lo hace de una manera creativa, no dictada. Al mismo tiempo, este supuesto "artista" que realiza una obra de arte e incluso expone en Festivales de reconocido prestigio, debe ceñirse a las normas que dicta la editorial y al mismo tiempo relacionar su imagen atractiva con un texto de una forma lo más exacta posible. En definitiva, la evolución del libro ilustrado hacia el álbum no ha sido otra que una cuestión de moda y formato con fines económicos. Aún queda mucho camino hasta conseguir la liberación total de la creatividad del artista en la utilización de su propio código narrativo. El inconveniente que plantea $\mathrm{Bal}^{49}$ sobre la insistencia de definir la Cultura Visual en lugar de crear su objeto de estudio, puede aplicarse al denominado álbum ilustrado, que en cierto modo, aunque alejado por el momento de las nuevas tecnologías propias del cine o la televisión, hemos apuntado que forma también parte de la misma categoría. Las diferentes definiciones que los estudios, fundamentalmente literarios, realizan sobre el álbum permanecen en el terreno del libro ilustrado y se centran especialmente en las figuras, escritas o dibujadas, empleadas para transmitir una narración.

El análisis realizado de manera separada por estas dos obras, literaria y plástica, bajo el mismo nombre, nos ha llevado en varias ocasiones a puntos de encuen-

\footnotetext{
48 Imágenes tomadas respectivamente de Cano 2006, op.cit. (nota 10), pp. 17 y 30.

$49 \mathrm{Bal}$ 2004, op cit. (nota 5), p. 21.
} 
tro espacial y temporal. Estas inflexiones unidas al proceso de elaboración de ambos, primero la escritura y después el encargo de viuda de Calvino a Cano, hacen que sea totalmente lícito pensar que la publicación de ambas en un formato libro puedan constituir un álbum ilustrado ajustado al formato editorial del mismo. Sin embargo esto no solo no es posible, sino que además pone en evidencia la situación forzada de esta pretendida cultura visual que necesita una redefinición para conseguir liberar todas las posibilidades creativas que encierra y que coartan la capacidad creativa del artista plástico.

La frontera entre la imagen y la palabra no es el amplio espacio marcado por el tiempo y el espacio entre el escritor y el ilustrador, puesto que en ocasiones pueden hallarse en la misma persona. Esta separación no produce otra cosa que cierta calma en el lector-observador que va confirmando su comprensión de lo que allí se cuenta, lo que duplica el libro ilustrado. Son como dos pruebas más en las que reafirmar sus propias imágenes, las infinitas imágenes que cada uno estructura instantáneamente según su experiencia atemporal. El cambio de código es instantáneo a pesar de la distancia y la diferencia aparente, como el niño bilingüe que se dirige a sus progenitores en diferentes idiomas sin reflexionar sobre la fonética o el grafismo de sus palabras. Las ciudades invisibles de Calvino y Cano son dos ejemplos entre muchas posibilidades en las que palabras e imágenes se mueven a uno y otro lado de la dinámica y delgada línea que separa poesía y pintura, por llamar de algún modo a ambos códigos.

El texto en el álbum ilustrado de Cano crea una tensión contraria a la calma del libro ilustrado. No aclara nada, desconciertan en todo caso. Vemos un rectángulo separado en diagonal por dos cromatismos distintos y nos comenta que "es el humor de quien la mira el que da su forma a la ciudad de Zemrude50". Está claro que la imagen se rige por unos códigos libres mientras que el texto utiliza códigos concretos, pero la frase desmonta la evidencia o al menos no soluciona nuestras dudas, que es lo que estamos esperando. Tampoco nos aclaran los vasos de Despinia ${ }^{51}$ con el texto extraído del correspondiente capítulo de Calvino, cuando la mirada espera confirmar que lo que está viendo e algo así como "la arena del desierto dentro del vaso transparente porque es el mismo material mineral y el agua porque es también incolora como el vaso y que color y material se funden en un objeto52", por elaborar alguna explicación más convincente que la que se nos muestra. Queda patente que las acuarelas de Cano no podrían ser un libro ilustrado y lo que comienza por un elemento de unión, como un intento de comunicación con el ya fallecido Calvino, titulando cada obra con el mismo nombre de mujer que idea Calvino para

\footnotetext{
50 Calvino 2011, op.cit. (nota 9), p. 80.

51 Calvino 2011, op.cit. (nota 9), pp. 32-33.

52 Se trata de una interpretación totalmente libre ante la observación de la ilustración que Cano realiza para Despinia.
} 
sus ciudades y realizando los primeros bocetos en el libro, pronto necesitan salir del (con)texto. Lo que en principio parecía un caligrama diciendo dos veces la misma cosa se escapa antes de caer en la redundancia.

Las imágenes en el álbum ilustrado de Calvino quedan en la imaginación del escritor italiano, fuera del libro directamente, en un espacio sin concretar ni determinar en ningún momento. Quizás intencionadamente esas ciudades debieron ser siempre invisibles y nunca haber sido propuestas como base de elaboración de ilustraciones. De hecho no existe actualmente ningún libro ilustrado publicado sobre Las ciudades invisibles de Calvino, a pesar del esencialismo visual ampliamente admitido de que una imagen vale más que mil palabras. Cada ciudad dibujada desde la imaginación de Calvino constituye una écfrasis, una descripción de una obra de arte y que según Hagstrum ${ }^{53}$ es una especie de nostalgia de la literatura por las artes visuales, al mismo tiempo que una cierta resistencia a su materialización. Este miedo, por parte de Calvino, y el deseo de que sus ciudades permaneciesen invisibles encerradas en su imaginación, puede que tenga que ver con el ejemplo del programa radiofónico "Rob y Ray" en el que se describen postales de viajes y siempre concluye con la frase "Cómo me gustaría que vosotros, los que estáis ahi fuera, en radiolandia, pudierais ver estas imágenes 54 ". Este deseo, fase ecfrástica de esperanza, se torna rápidamente en un contradeseo ante el riesgo de la pérdida del encanto. Algo así como el sentimiento de fraude de novelas fantásticas llevadas al cine o la televisión, o la pipa de Magritte flotando como un sueño sin concreción de espacio tiempo.

Las relaciones tradicionales entre lenguaje e imagen en el libro ilustrado como las distribuciones de la página, el diálogo semántico entre ambos, la armonía en su representación, dan lugar a una especie de caligrama, una duplicidad que no puede ser leída y observada al mismo tiempo: lo que se ve y se lee está callado en la visión y oculto en la lectura. Sin embargo, añade Foucault, a diferencia del caligrama, el libro ilustrado presenta un pequeño espacio blanco que se extiende por encima de las palabras y por debajo de los dibujos donde ocurren las relaciones. El caligrama ha reabsorbido este intersticio y la imagen y el texto caen cada uno por su lado según la gravitación propia de cada uno de ellos del mismo modo que se va "De la pizarra a la imagen, de la imagen al texto, del texto a la voz, una especie de dedo indice general señala, muestra, fija, señaliza, impone un sistema de reflexiones, intenta estabilizar un espacio único 55". Un ir y venir del texto a la ilustración y de la ilustración al texto posible en el álbum ilustrado en tanto que el uno y la otra fun-

\footnotetext{
53 Hagstrum, J., The Sister Arts: The Tradition of Literary Pictorialism and English Poetry from Dryden to Gray, University of Chicago Press, Chicago, 1982.

54 Frase y ejemplo tomados de W.J.T. Mitchell 2009, op. cit. (nota 27), pp. 137-138 al hablar de La écfrasis y el otro.

55 Foucault 1993, op cit. (nota 46) p. 44.
} 
cionan de manera autónoma alejadas del sometimiento a unas normas que restan creatividad al escritor o al artista plástico.

\section{Conclusiones}

El ejemplo elegido para este estudio y que hemos justificado por el paralelismo que existe entre el proceso que lleva a cabo el pintor Pedro Cano a la hora de inspirarse en el texto de Calvino con la elaboración del álbum ilustrado, nos indica que existe un modelo de cultura visual, objeto y acto, desvinculado del formato libro, por lo que su concepto debe ser reformulado atendiendo a estudios más profundos. Las investigaciones no deben basarse en la separación entre escritura e imagen como lo real y lo mágico respectivamente. Calvino materializa a través de la escritura imágenes u objetos que promueven a su vez nuevas imágenes en el acto visual, a través de sensaciones similares a las producidas en la participación de una obra plástica. Del mismo modo Cano, salvo algunas ciudades que representa fielmente al texto de Calvino, reinterpreta las imágenes sugiriendo una historia paralela.

A lo largo de este artículo hemos puesto de manifiesto que no resulta fácil establecer una frontera precisa entre imagen y palabra en el álbum ilustrado. La imagen es al mismo tiempo la ciudad invisible de Calvino y la acuarela de Cano. El texto se puede leer en las descripciones de las ciudades del escritor italiano y en los fragmentos que Cano hace suyos antes que reinventar explicaciones propias. En definitiva palabra e imagen, se contaminan una a otra aún dentro de la dualidad que proponen ambos artistas literario y plástico. Sin embargo existe una tendencia actual a realizar una delimitación artificial, basada en el formato impuesto por editoriales, entre ambas formas de expresión principalmente porque el álbum no ha sido liberado del libro ilustrado del que deriva.

Con el fin de seguir avanzando en las posibilidades del álbum sería quizás necesaria una implicación de literatura y arte dentro de la cultura visual, es decir, a través de una metodología que no subordine el objeto como punto de partida teorético sino como partícipe activo. Solo en este campo de estudio sería posible delimitar el libro y el álbum, el texto y la imagen, para llegar a comprender las interrelaciones que ocurren en la obra final. 